\title{
MNC Staffing policies for the managing director position in foreign subsidiaries : the results of an innovative research method
}

Citation for published version (APA):

Harzing, A-W. (1996). MNC Staffing policies for the managing director position in foreign subsidiaries : the results of an innovative research method. NIBOR, Netherlands Institute of Business Organization and Strategy Research. NIBOR Research Memorandum No. 03 https://doi.org/10.26481/umanib.1996003

Document status and date:

Published: 01/01/1996

DOI:

10.26481/umanib.1996003

Document Version:

Publisher's PDF, also known as Version of record

Please check the document version of this publication:

- A submitted manuscript is the version of the article upon submission and before peer-review. There can be important differences between the submitted version and the official published version of record.

People interested in the research are advised to contact the author for the final version of the publication, or visit the DOI to the publisher's website.

- The final author version and the galley proof are versions of the publication after peer review.

- The final published version features the final layout of the paper including the volume, issue and page numbers.

Link to publication

\footnotetext{
General rights rights.

- You may freely distribute the URL identifying the publication in the public portal. please follow below link for the End User Agreement:

www.umlib.nl/taverne-license

Take down policy

If you believe that this document breaches copyright please contact us at:

repository@maastrichtuniversity.nl

providing details and we will investigate your claim.
}

Copyright and moral rights for the publications made accessible in the public portal are retained by the authors and/or other copyright owners and it is a condition of accessing publications that users recognise and abide by the legal requirements associated with these

- Users may download and print one copy of any publication from the public portal for the purpose of private study or research.

- You may not further distribute the material or use it for any profit-making activity or commercial gain

If the publication is distributed under the terms of Article $25 \mathrm{fa}$ of the Dutch Copyright Act, indicated by the "Taverne" license above, 
MNC Staffing policies for the managing director position in foreign subsidiaries: The results of an innovative research method

A-W. Harzing

NIBOR/RM/96/03

http://www.unimaas.nl/ document/fdewb.htm

J.E.Lit. code:

$n i b o r$

Netherlands Institute of

Business Organization

and Strategy Research

University of Maastricht

Faculty of Economics and Business Administration

P.O. Box 616

6200 MD Maastricht

The Netherlands

Phone: ++31 43 - 3883805

Fax : ++3143-3258495 
RESEARCH NOTE:

ABOUT THE PAUCITY OF EMPIRICAL RESEARCH IN IHRM:

A TEST OF DOWNES FRAMEWORK OF STAFFING FOREIGN SUBSIDIARIES

\section{Anne-Wil Harzing}

Assistant Professor International and Comparative Management

Maastricht University, the Netherlands 


\begin{abstract}
This research note draws the attention to the harmful consequence of a serious lack of empirical research in the field of International Human Resource Management: myth-building on the basis of one or two publications. The apparent myth of high expatriate failure rates is shortly discussed. To prevent another myth from appearing, this time in the field of staffing policies, this research note provides an empirical test of the framework proposed by Meredith Downes (1996) for making decisions about staffing foreign subsidiaries. The propositions set forward by Downes are tested using a database of nearly 1800 subsidiaries located in twenty-two different countries. Headquarters of these subsidiaries are located in nine different countries and operate in eight different industries. Although the variables suggested by Downes have a fair explanatory power, some of the specific propositions had to be rejected.
\end{abstract}

\title{
INTRODUCTION
}

Virtually every publication on expatriate management starts with two issues. First, over the last three decades it has become almost "traditional" to open an article on expatriate management by stating that expatriate failure rates are (very) high. In a recent article (Harzing, 1995a), it was argued that there is in fact very little empirical proof for the persistent claim of high expatriate failure rates. This claim appears to be based on very shaky foundations dating back to the 1960s, and has taken strong roots by the fact that many authors in the field of expatriate management lend credence to the claim simply by continuously repeating it without offering any empirical support. This is not surprising, since no largescale empirical work has been done on this subject for more than 15 years.

A second issue that usually draws the attention is MNC staffing policies. Do companies employ Parent Country Nationals (PCNs), Host Country Nationals (HCNs) or Third Country Nationals (TCNs) as (top) managers in their subsidiaries and in which circumstances is one option favored above another? Although many publications focus on the advantages and disadvantages of using expatriates as opposed to local managers and indicate the factors influencing MNC staffing policies (see e.g. Hamill, 1989; Dowling and Schuler, 1991; Hendry, 1994; Hodgetts and Luthans, 1994; Mead, 1994; Borg and Harzing, 1995; Briscoe, 1995, Fatehi, 1996), there are surprisingly few empirical studies that examine MNC staffing policies. All of the above publications refer to Tung (1981, 1982, 1987) in this respect. Although Tung's study was a primer in the field, it is now more than 15 years old. Recently, Kopp (1994) compared international human resource policies in Japanese, European and United States multinationals. ${ }^{1}$ One of the issues studied was the nationality of top managers in overseas operations. Kopp's study confirmed Tung's finding that Japanese companies employ the largest number of PCNs in their subsidiaries, US companies the smallest number, while the number of PCNs in subsidiaries in European companies lies between these two extremes. No data were available however, as to the influence of host country variables on staffing policies. 
Even more recently, this journal included an article by Downes (1996) who provided an interesting analysis of the possible influence of political risk, cultural distance and specific cultural dimensions on staffing policies and provided testable propositions about the influence of these variables on the proportion of HCNs or PCNs in key subsidiary positions. Again however, no empirical tests were provided. Although the value of sound conceptual work is duly recognized, we fear that another myth might be created if the conclusions of Downes' article are accepted without solid empirical foundations.

As part of a larger research project, we collected information on the nationality of the managing director for nearly 1800 subsidiaries, located in twenty-two different countries. The multinationals involved were headquartered in nine different countries and operated in eight different industries ${ }^{2}$. The subsidiaries had on average 1590 employees (min. 2 and max. 59062, standard deviation:4775) and were on average 39 years old (min. 2 and max. 284, standard deviation: 36). These data provided an excellent opportunity to test some of the propositions put forward by Downes ${ }^{3}$. The remainder of this research note will therefore be devoted to this purpose. It will be concluded with a short statement on the importance of empirical research in international (human resource) management.

\section{PROPOSITIONS}

The framework reproduced in Figure 1 was put forward by Meredith Downes in her article "SIHRM: Overseas Staffing Considerations at the Environmental Level.". All of the propositions she formulated have been replicated in

Table 1, preceded by their original numbers. The first proposition, which involves the influence of host government bargaining power on the staffing decision cannot be tested with the data available. For propositions 3, 4 and 7 only part a) can be tested, since the number of TCNs in my sample is too small to permit statistical tests.

Figure 1: An interactive framework for overseas staffing, source: Downes (1996)

Table 1: Summary of propositions put forward by Downes (1996)

Proposition 1: The greater the bargaining power of the host government, the greater the proposition of HCNs (as opposed to PCNs and TCNs) in key subsidiary positions.

Proposition 2: In politically risky environments the bargaining power of the host government is limited and hence a greater proportion of PCNs will be placed in key positions.

Proposition 3a: In environments characterized by a low level of political risk, cultural distance between home and host countries will be positively related to the proportion of HCNs in key subsidiary positions. 
Proposition 3b: In environments characterized by a high level of political risk, cultural distance between home and host countries will be positively related to the proportion of TCNs in key subsidiary positions. Proposition 4a: When the level of political risk in the host country is low and when host and home countries are culturally similar, MNCs will use a greater proportion of PCNs in high power distance countries.

Proposition 4b: When the level of political risk in the host country is high and when host and home countries are culturally distant, MNCs will use a greater proportion of TCNs in high power distance countries.

Proposition 5: When the level of political risk in the host country is low and when host and home countries are culturally similar, MNCs will use a greater proportion of PCNs in subsidiaries in individualist countries.

Proposition 6: Regardless of political risk or cultural distance, MNCs will use a greater proportion of HCNs in subsidiaries in high uncertainty avoidance countries

Proposition 7a: When the level of political risk in the host country is low and when host and home countries are culturally similar, MNCs will use a greater proportion of HCNs in masculine countries.

Proposition 7b: When the level of political risk in the host country is high and when host and home countries are culturally distant, MNCs will use a greater proportion of TCNs in masculine countries.

\section{METHODOLOGY}

The sample used in this research note to test the propositions put forward by Downes has been collected as part of a larger research project on control mechanisms in MNCs. In this project questionnaires (some $1650^{4}$ in total) were to sent out to subsidiaries of MNCs in 22 countries. As personalisation of the letter is usually thought to increase response rates (see e.g. Dillman, 1978; Yu and Cooper, 1983; Jobber, 1986; Harvey, 1987; Fox, Crask and Kim, 1988, LaGarce and Kuhn, 1995) the name of the managing director/CEO/president of the subsidiary was written down while verifying the addresses in address books 5 . In this process some pleasant distraction was found in guessing the nationality of the managing directors. It seemed surprisingly easy in most cases to guess their nationality simply based on their names (mostly both first and last names were available). Only later it became apparent that these data could be a valuable source of information in themselves, and we noted down systematically whether the managing director was thought to be a PCN, a HCN or a TCN. A full justification of why this research method could be valid in general can be found in Harzing (1995b). For this particular study, sufficient justification can be found in considering the number of successful classifications in a sub-sample of the original sample. As indicated above, the author's study on control mechanisms involved a mail questionnaire to 1650 subsidiaries. On this questionnaire, respondents were asked to indicate their nationality, which provided a check on the original classification by name alone. Out of 287 questionnaires returned a verification was not possible in 69 cases, because the respondent preferred to remain anonymous, the respondent was not the same person the questionnaire was sent to, the respondent's name was unavailable or the respondent's name could not be classified in the first place. Out of the remaining 218 cases, 212 had been classified correctly. In six cases the respondent turned out to be a TCN instead of a PCN or HCN. So in fact less than $3 \%$ of the cases was classified incorrectly, not a bad result when we look at the usual levels of significance used in academic research. 
Political risk indicators provided by Political Risk Services are used to measure the level of political risk for all of the twenty-two countries. A recent article that compared three approaches to measure political risk (Howell and Chaddick, 1994) found Political Risk Services' indicators to have the highest explanatory power. Kogut and Singh's (1988) composite index, which summarizes the difference between two countries on each of Hofstede's dimensions, is used to measure the overall cultural distance between home and host country. Hofstede's $(1980,1991)$ original dimensions are used to test the effect of the separate dimensions on staffing policies. Clusters for the level of political risk (high or low) and cultural distance (high or low) were constructed by a k-means cluster analysis. These clusters were used for models $3 \& 4$ only. Models $1 \& 2$ used the original scores for political risk and cultural distance as a continuous variable.

To explore the influence of the variables described above on the chance of having a $\mathrm{HCN}$ as a managing director, a binomial logistic regression analysis was conducted. The nationality of the managing director is captured by a dummy variable that takes the value of one if the managing director is a $\mathrm{HCN}$ and zero if the managing director is a PCN. In the binomial logistic model the probability of a $\mathrm{HCN}$ is explained by the variables political risk, overall cultural distance, and the separate cultural dimensions power distance, individualism, uncertainty avoidance and masculinity. The regression coefficients estimate the impact of the independent variable on the probability that the managing director will be a $\mathrm{HCN}$. A positive sign for the coefficient means that a variable increases the probability of a $\mathrm{HCN}$, a negative sign indicates the reverse. The model can be expressed as:

$$
\mathrm{P}(\mathrm{Y})=1 /\left(1+\mathrm{e}^{-\mathrm{Z}}\right),
$$

where $\mathrm{Y}$ is the dependent variable (the selection/occurrence of a $\mathrm{HCN}$ in this case), $\mathrm{Z}$ is a linear combination of the independent variables

$$
Z=\beta_{0}+\beta_{1} X_{1}+\beta_{2} X_{2}+\ldots+\beta_{n} X_{n}
$$

where $\beta_{0}$ is the intercept, $\beta_{1} \ldots \beta_{n}$ the regression coefficients and $X_{1 . .} X_{n}$ the independent variables.

The models were estimated with SPSS 6.1 using the maximum-likelihood method. The null hypothesis that all $\beta$ 's, except $\beta_{0}$ are zero can be tested with the model $\chi^{2}$ When the model $\chi^{2}$ is significant, this null hypothesis can be rejected. A test that a specific coefficient is zero can be based on the Wald statistic. Significance levels of separate coefficients based on the Wald statistic are indicated in the models in Table 2 and Table 3. The partial correlation of each predictor variable with the dependent variable is indicated by $R$. $R$ can range in value from -1 to +1 . A positive value indicates that as the variable increases in value, so does the likelihood of the event occurring. If $R$ is negative, the opposite is true.

\section{RESULTS}

Model 1 (see Table 2) includes all six variables and can be used to test propositions 2 and 6. 
Proposition 6 can be accepted as uncertainty avoidance is positively (sig. 0.0026 ) related to the chance of encountering a $\mathrm{HCN}$. Although the sign for political risk (proposition 2) is in the expected direction it is not significant (sig. 0.4334). Power distance is strongly related to political risk (0.6243, sig. 0.000 ), however, suggesting the presence of multicollinearity. Therefore another model was run (model 2, see Table 2), without the independent variable power distance. In this model political risk indeed shows a significant (0.0152) negative relationship with the chance of encountering a HCN and thus proposition 2 can be accepted as well.

These two models also show that, disregarding the level of political risk and cultural distance for the moment, there is a significant negative relationship between both masculinity and power distance and the chance of having a $\mathrm{HCN}$ as a managing director. Further, in model 2 the positive relationship between individualism and the chance of encountering a HCN is significant (sig. 0.0194). These relationships persist even when we run models for each headquarters country and each industry separately, although they are not significant for each sub-sample. Disregarding the level of political risk, the amount of cultural distance is negatively related to the chance of having a $\mathrm{HCN}$ as managing director. For the three countries that send out the largest proportion of PCNs (Japan, Germany and the Netherlands) this relationship is reversed, however, although the significance is marginal $(0.09,0.13$ and 0.04 respectively).

Table 2: Results of logistic regression, $H C N$ versus $P C N, H C N=1$

\begin{tabular}{|c|c|c|c|c|}
\hline \multirow[b]{2}{*}{ VARIABLES } & \multicolumn{2}{|c|}{ Model 1: test of propositions 2 and 6} & \multicolumn{2}{|c|}{ Model 2: test of proposition 6} \\
\hline & Coefficients & $\mathrm{R}$ & Coefficients & $\mathrm{R}$ \\
\hline Political risk & $\begin{array}{l}-0.0080 \\
(0.0102)\end{array}$ & 0.0000 & $\begin{array}{r}-0.0227 \star \\
(0.0093)\end{array}$ & -0.0410 \\
\hline Cultural distance & $\begin{array}{l}-0.1670 * \star \star \\
(0.0502)\end{array}$ & -0.0627 & $\begin{array}{l}-0.2076 * \star \star \\
(0.0486)\end{array}$ & -0.0838 \\
\hline PD Subsidiary country & $\begin{array}{l}-0.0164 * \star \star \\
(0.0044)\end{array}$ & -0.0715 & & \\
\hline IDV Subsidiary country & $\begin{array}{l}0.0017 \\
(0.0034)\end{array}$ & 0.0000 & $\begin{array}{c}-0.0070 * \\
(0.0030)\end{array}$ & 0.0387 \\
\hline UA Subsidiary country & $\begin{array}{l}0.0076 * \star \\
(0.0025)\end{array}$ & 0.0552 & $\begin{array}{l}0.0047 \star \\
(0.0024)\end{array}$ & 0.0283 \\
\hline MAS Subsidiary country & $\begin{array}{l}-0.0114 * \star \star \\
(0.0026)\end{array}$ & -0.0867 & $\begin{array}{l}-0.0104 * \star \star \\
(0.0025)\end{array}$ & -0.0801 \\
\hline Constant & $\begin{array}{l}1.7758 * \star \star \\
(0.4138)\end{array}$ & & $\begin{array}{l}1.1120 * \star \\
(0.3662)\end{array}$ & \\
\hline Model $\chi^{2}$ & 109.949 & & 95.824 & \\
\hline p value & 0.000 & & 0.000 & \\
\hline n & 1748 & & 1748 & \\
\hline \% of correct classifications & $65.39 \%$ & & $64.87 \%$ & \\
\hline Base line rate & $53.16 \%$ & & $53.16 \%$ & \\
\hline Classification improvement & $23.00 \%$ & & $22.02 \%$ & \\
\hline Specificity & $23.24 \%$ & & $24.16 \%$ & \\
\hline Sensitivity & $90.59 \%$ & & $89.21 \%$ & \\
\hline
\end{tabular}

Although the first two models give some indication towards the validity of propositions $3,4 \mathrm{a}, 5$ and $7 \mathrm{a}$, the actual propositions included two moderating variables in the form of political risk and cultural distance. First, cultural distance is assumed have a different impact under situations of either low or high political risk. Second, the proposed relationship between Hofstede's cultural dimensions and the 
preferred staffing policies will differ according to the specific combination of political and cultural similarity. The specific influence of these variables can be found in the propositions as reproduced in

Table 1. Model 3 (Table 3) therefore includes only the cases with a low level of political risk and can be used to test proposition 3a, which has to be rejected on the basis of the data available. Cultural distance has a significant (0.0001) negative relationship with the chance of having a $\mathrm{HCN}$ as a managing director. Model 4 (Table 3) reduces the sample to a subset that combines a low level of political risk with a high degree of cultural similarity. This model can be used to test the propositions 4a, 5 and 7a. Proposition 4a can be accepted: MNCs indeed seem to prefer PCNs in high power distance countries. Propositions 5 and 7 a both have to be rejected however, since the opposite relationship is statistically significant. $\mathrm{HCNs}$ are more likely to be found in individualistic, feminine countries. ${ }^{6}$

Table 3: Results of logistic regression continued, $H C N$ versus $P C N, H C N=1$

\section{VARIABLES}

Cultural distance

PD Subsidiary country

IDV Subsidiary country

UA Subsidiary country

MAS Subsidiary country

Constant

Model $\chi^{2}$

p value

n

\% of correct classifications

Base line rate

Classification improvement

Specificity

Sensitivity

$* * * \mathrm{p}<0.001, * * \mathrm{p}<0.01, * \mathrm{p}<0.05,2$-tailed
Model 3: test of proposition 3a

Model 4: test of propositions 4a, 5 ,

\begin{tabular}{|c|c|c|c|}
\hline \multirow[b]{2}{*}{ Coefficients } & & \multicolumn{2}{|c|}{$7 a$} \\
\hline & $\mathrm{R}$ & Coefficients & $\mathrm{R}$ \\
\hline $\begin{array}{l}-0.2213 * \star \star \\
(0.0547)\end{array}$ & -0.0844 & & \\
\hline $\begin{array}{l}-0.0183 * \star \star \\
(0.0042)\end{array}$ & -0.0910 & $\begin{array}{l}-0.0135 * \star \star \\
(0.0043)\end{array}$ & -0.0721 \\
\hline $\begin{array}{l}0.0026 \\
(0.0036)\end{array}$ & 0.0000 & $\begin{array}{l}0.0110 * \\
(0.0051)\end{array}$ & 0.0418 \\
\hline $\begin{array}{l}0.0066 * \star \\
(0.0026)\end{array}$ & 0.0484 & & \\
\hline $\begin{array}{l}-0.0132 \star \star \star \\
(0.0026) \\
1.8875 \star \star \star \\
(0.4105)\end{array}$ & -0.1061 & $\begin{array}{l}-0.0093 \star \star \star \\
(0.0030) \\
1.1401 \star \\
(0.4660)\end{array}$ & -0.0716 \\
\hline 99.631 & & 26.718 & \\
\hline 0.000 & & 0.000 & \\
\hline 1554 & & 1223 & \\
\hline $67.31 \%$ & & $70.40 \%$ & \\
\hline $54.19 \%$ & & $58.26 \%$ & \\
\hline $24.21 \%$ & & $20.84 \%$ & \\
\hline $17.75 \%$ & & $0.83 \%$ & \\
\hline $94.61 \%$ & & $99.77 \%$ & \\
\hline
\end{tabular}

\section{DISCUSSION}

Using logistic regression analysis six of the ten propositions put forward by Downes (1996) could be tested. Three of these could be accepted. PCNs indeed seem to be more likely in high political risk environments, a relationship also found by Boyacigiller (1990) in her study of one large US bank. One might wonder, however, whether market attractiveness of a country could not overcome political risk considerations and hence increase the bargaining power of the government. ${ }^{7}$ Further, in our view, the reason for a high level of PCNs in high political risk environments is not so much related to the bargaining power of the government, but rather to the MNC's desire to control a high-risk investment. A second proposition that could be accepted is that regardless of the level of political risk and cultural 
distance, HCNs are more likely in high uncertainty avoiding countries. As Downes suggests this might be due to the fact that people in high uncertainty avoiding countries have a basic distrust of working for a foreign manager. As also indicated by Downes a reverse reasoning could explain the positive relationship between power distance and the proportion of PCNs, as PCNs will be well received in high power distance countries.

The fact that cultural distance is negatively and not positively related to the chance of having a $\mathrm{HCN}$ as a managing director is not surprising. A negative relationship was also found by Boyacigiller (1990). It might indeed be more difficult to be efficient for PCNs in culturally different environments as Downes suggested. On the other hand, companies may feel obliged to use PCNs to facilitate communication with headquarters - one of the main reasons for expatriation (Harzing, 1996a) precisely because of this cultural difference. This necessity will be greater for highly integrated than for loosely coupled MNCs. The positive relationship between individualism and the proportion of HCNs is not surprising either, given the strong negative correlation between individualism and power distance also signaled by Downes. The underlying rationale for this relationship is less clear, however. Most likely, individualism can be regarded as a proxy for highly developed Western countries that have a large supply of qualified labor and are therefore a less likely object for expatriation. No full explanation has been found for the significant negative relationship between masculinity and the proportion of HCNs. It is highly likely, however, that this negative relationship is caused by other, underlying variables. Including for instance the size and age of the subsidiary and the into the regression analysis ${ }^{8}$, reduces the explanatory power of the masculinity dimension, although the negative relationship is still significant at the 0.047 level. Subsidiaries in masculine countries are apparently larger and more recently established. Also much of the negative relationship is caused by the fact that the highly feminine Scandinavian countries have a very low incidence of PCNs as a managing director. Based on the data available, we cannot establish whether this is due to their femininity, which would contradict the proposition, or to other reasons, such as for instance a high level of qualified labour or a low attractiveness of these countries for expatriates. Even when we exclude the Scandinavian countries, however, we do not find a significant positive relationship between masculinity and the incidence of a $\mathrm{HCN}$ as a managing director. This problem does clearly highlight the necessity, however, of using even larger samples in order to be able to isolate the various influences.

One could wonder whether the observed relationships between the various cultural dimensions and staffing policies are not simply a reflection of cultural distance. For instance many of the headquarters countries score low on power distance and uncertainty avoidance, while many of the subsidiary countries with a large number of expatriates (Latin America, Asia) score high on these indices. The fact, however, that the cultural indices remain significant when cultural distance is included in the model (though slightly less so than without this inclusion), clearly shows that the 
cultural indices have an additional explanatory power in predicting the likelihood of encountering a $\mathrm{HCN}$ as a managing director.

All of the models described in the previous section have highly significant $\chi^{2}$ values. In addition to this, many of the coefficients have high significance levels. The variables suggested by Downes certainly seem to have a fair explanatory power (though not always in the predicted direction). The models predict the chance of encountering a HCN better than a random model would ${ }^{9}$, with classification improvements between $20.84 \%$ and $24.21 \%$. These improvements fall below the minimum improvement of $25 \%$ as suggested by Hair et al. (1995), however. Further, although the models' sensitivity (their ability to predict HCNs) is excellent, their specificity (their ability to predict PCNs) is very weak indeed.

A larger improvement was realized by including the country of location of headquarters, the year of foundation of the subsidiary and the number of employees of the MNC as a whole as independent variables in the model (Harzing, forth). Staffing policies were also shown to vary across industries, although this effect was not very strong and the rationales were inconclusive. Future research could identify a number of industry characteristics that are publicly available and might be entered into the analysis to substitute the industry variable. Concentration and integration could for instance be used as measures of globalization, while advertising intensity might be a measure for multidomestic orientation (see Ghoshal and Nohria, 1993 and Kobrin, 1991). Firms in globally integrated industries are likely to employ a larger number of PCNs in their subsidiaries than firms in multidomestic industries, in which responsiveness to the local market is of prime importance. Additional structural characteristics that might be of influence are the type of subsidiary (sales/service, production, assembly or R\&D), the entry mode (greenfield or acquisition) and the percentage of ownership. Production, assembly or R\&D subsidiaries are more likely to have an expatriate as managing director as these subsidiaries are of vital importance for headquarters and are more likely to experience personal control from headquarters. Greenfield subsidiaries will also be more likely to have an expatriate as managing director as they have to be started up from scratch. Headquarters is unlikely to interfere personally with well-established acquired subsidiaries as long as they achieve satisfactory results. Finally, a greater percentage of ownership increases the company's bargaining power and hence the likelihood that a PCN will be accepted as a managing director. A major advantage of all these measures is that they can be acquired via desk-research, thus reducing the need for international mail surveys that usually generate very low response rates (Harzing, 1996b).

A reliance on large samples (and hence desk research) is all the more necessary as many of these effects interact with each other. For example, sales/service subsidiaries are likely to be small. Both factors would lead to a higher likelihood of HCNs. On average, acquisitions will be older than greenfield subsidiaries and they might be more appropriate in a multidomestic industry where local knowledge is important. Previous studies have shown that UK companies have the largest number and 
Japanese companies the smallest number of acquisitions (Wilson, 1980; Kogut and Singh, 1988; Cho and Padmanabhan, 1995). Added together, these factors point in the same direction: a larger chance of a $\mathrm{HCN}$ as a managing director. To separate these different influences a very large scale and systematically constructed sample will have to be investigated.

In addition to the variables identified above, a multitude of other variables could be suggested. For instance, the variables identified in Rosenzweig and Nohria (1994) and Taylor, Beechler and Napier (1996) as influencing the degree of similarity between affiliate and parent HRM system (e.g. degree of local embeddedness, communication and resource flows, strategic role of the subsidiary) would also influence the staffing policy. Unfortunately, the test of the influence of these types of variables can hardly be done via desk research alone and will therefore have to be limited to small samples. In our view, the best way to attain progress in this field of research is to start with large scale desk research in order to be able to formulate more focused hypotheses, that could then be tested using interviews or surveys. In view of the difficulty of obtaining cooperation in international management research, it is our firm conviction that secondary data should be a international researcher's first option and that he or she should turn to primary research data only after desk research possibilities have been fully explored.

\section{IMPLICATIONS FOR RESEARCH AND PRACTICE}

The discussion in this article has shown that many factors have to be included in the decision about staffing policies for foreign subsidiaries. Since the state of knowledge about the factors that influence the choice for either a local or an expatriate manager is still very limited, it would not be sensible to offer any specific prescriptions to international human resource managers. What can be concluded from our findings is that political and cultural factors should certainly not be overlooked in taking a foreign staffing decision.

This research note has shown that both political and cultural factors might influence an MNC's staffing policy. In this sense this note confirms the framework put forward by Downes (1996). Many of the specific propositions resulting from this framework were not confirmed in a large scale empirical test, however. Although Downes duly notes the limitations of her propositions and gives a very interesting start to the discussion, we would not like to see some myths regarding the relationship between political risk, culture and staffing policies to be added to the myth of high expatriate failure rates. As myths of this type are created by a severe lack of empirical research in international (human resource) management, we would like to end this article with a strong plea for more empirical research in this field. And to cite Schuler and Florkowski (1996:389): "This goes beyond descriptive case studies and surveys conveying frequency distributions, modes of analysis that still represent a large proportion of the reported research in this field." 


\section{LITERATURE}

Borg, M., Harzing, A.W.K. (1995): Composing an international staff, in Harzing, A.W.K.; Van Ruysseveldt, J.: International Human Resource Management, pp. 179-204, London: Sage.

Boyacigiller, N. (1990): The role of expatriates in the management of interdependence, complexity and risk in multinational corporations, Journal of International Business Studies, vol. 21 no. 3, pp. 357-381.

Briscoe, D.R. (1995): International Human Resource Management, Englewood Cliffs, NJ: Prentice Hall.

Cho, K.R., Padmanabhan, P. (1995): Acquisition Versus New Venture: The Choice of Foreign Establishment Mode by Japanese Firms, Journal of International Management, vol. 1 no. 3 (Fall), pp. 255-286.

Dillman, R. (1978): The total design method, New York: John Wiley and Sons.

Dowling, P.J., Schuler, R.S. (1990): International Dimensions of Human Resource Management, Boston: PWS-Kent.

Downes, M. (1996): SIHRM: Overseas Staffing Considerations at the Environmental Level, Journal of International Management, vol. 2, no. 1, pp. 31-50.

Fatehi, K. (1996): International Management, New Jersey: Prentice Hall.

Fox, R.J., Crask, M.R.; Kim, J. (1988): Mail survey response rate: a meta analysis of selected techniques for inducing response, Public Opinion Quarterly, vol. 52, pp. 467-491.

Ghoshal, S., Nohria, N. (1993): Horses for Courses: Organizational Forms for Multinational Corporations, Sloan Management Review (Winter), pp. 23-35.

Hair, J.F, et al. (1995), Multivariate Data Analysis wit Readings, Englewood Clifss, New Jersey: Prentice Hall.

Hamill, J. (1989): Expatriate Policies in British Multinationals, Journal of General Management, vol. 14 no. 4 , pp. 18-33.

Harvey, L. (1987): Factors affecting response rates to mailed questionnares: a comprehensive literature review, Journal of the Market Research Society, vol. 29, pp. 341-353.

Harzing, A.W.K. (1995a): The Persistent Myth of High Expatriate Failure Rates, The International Journal of Human Resource Management, vol. 6 no. 2, pp. 457-475.

Harzing, A.W.K. (1995b): MNC Staffing Policies: In Search of Explanations for Variety, paper presented at the $21^{\text {st }}$ EIBA conference, Urbino, 10-12 December, 1995

Harzing, A.W.K. (1996a): Environment, Strategy, Structure, Control Mechanisms, and Human Resource Management, Company report of doctoral research project, Maastricht: University of Limburg.

Harzing, A.W.K. (1996b): How to survive international mail surveys: an inside story, proceedings of the $22^{\text {nd }}$ EIBA conference, Stockholm, 15-17 December, 1996.

Harzing, A.W.K. (1996): MNC Staffing policies for the CEO-position in foreign subsidiaries. The results of an innovative research method, manuscript under review at Management International Review.

Hendry, C. (1994): Human Resource Strategies for International Growth, London: Routledge.

Hodgetts, R.M., Luthans, F. (1994): International Management, New York: McGraw-Hill.

Hofstede, G. (1980): Culture's Consequences. International Differences in Work-Related Values, London: SAGE Publications.

Hofstede, G. (1991): Cultures and Organizations: Software of the Mind, London: McGraw-Hill.

Howell, L.D.; Chaddick, B. (1994): Models of Political Risk for Foreign Investment and Trade, Columbia Journal of World Business, Fall,70-91.

Jobber, D. (1986): Improving Response Rates in Industrial Mail Surveys, Industrial Marketing Management, vol. 15, pp. 183-195.

Kobrin, S.J. (1991): An Empirical Analysis of the Determinants of Global Integration, Strategic Management Journal, vol. 12, 17-31.

Kogut, B., Singh, H. (1988): The Effect of National Culture on the Choice of Entry Mode, Journal of International Business Studies (Fall), pp. 411-432.

Kopp, R. (1994): International Human Resource Policies and Practices in Japanese, European and United States Multinationals, Human Resource Management, vol. 33 no. 4 (Winter), pp. 581-599.

LaGarce, R., Kuhn, L.D. (1995): The Effect of Visual Stimuli on Mail Survey Response Rates, Industrial Marketing Management, vol. 24, pp. 11-18.

Mead, R. (1994): International Management. Cross Cultural Dimensions, Oxford: Blackwell.

Morrison, D. (1974): Discriminant Analysis, in: Ferber, R. (ed.) Handbook of Marketing Research, New York: Wiley, pp. 2442-2457.

Schuler, R.S; Florkowski, G.W. (1996): International Human Resource Mangement, in: Punnett, B.J.; Shenkar, O., Handbook for international management research, Cambridge: Blackwell, pp. 351-402.

Scullion, H. (1991): Why Companies Prefer to Use Expatriates, Personnel Management, vol. 23 no. 11, pp. 3235.

Tung, R.L. (1981): Selection and Training of Personnel for Overseas Assignments, Columbia Journal of World Business, vol. 15 (Spring), pp. 68-78.

Tung, R.L. (1982): Selection and Training Procedures of U.S., European, and Japanese Multinationals, California Management Review, vol. 25 no. 1 (Fall), pp. 57-71. 
Tung, R.L. (1987): Expatriate Assignments: Enhancing Success and Minimizing Failure, Academy of Management Executive, vol. 1 no. 2, pp. 117-125.

Wilson, B. (1980): The propensity of multinational companies to expand through acquisitions, Journal of International Business Studies, vol. 12, pp. 59-65.

Youssef, S.M. (1973): The Integration of Local Nationals into the Managerial Hierarchy of American Overseas Subsidiaries: An Exploratory Study, Academy of Management Journal, vol. 16 no. 1, pp. 24-34.

Yu, J., Cooper, H. (1983): A Quantitative Review of Research Design Effects on Response Rates to Questionnaires, Journal of Marketing Research, vol. XX (Feb), pp. 36-44.

${ }^{1}$ There are a handful of other studies that discuss the choice between expatriate and local managers (Franko, 1973; Youssef, 1973; Hamill, 1989; Scullion, 1991). Unfortunately, these studies focus on very limited samples (e.g. two subsidiaries of one American MNC or only British MNCs) and provide very fragmented empirical information.

2 The subsidiary countries included in the sample are: Argentina, Austria, Belgium, Brazil, Denmark, Finland, France, Germany, Hong Kong, Ireland, Italy, Japan, Mexico, Netherlands, Norway, Singapore, Spain, Sweden, Switzerland, UK, US, Venezuela. The countries of headquarters' location included in the sample are: Finland, France, Germany, Japan, Netherlands, Sweden, Switzerland, UK, US. The industries included in the sample are: electronics, computers, motor vehicles and parts, petroleum (products), food and beverages, pharmaceutical, paper and chemical.

${ }^{3}$ Please note that Downes propositions refer to the proportion of HCNs in key subsidiary positions, while our data deal with the nationality of the managing director only. The results from the smaller sample of firms that responded to our survey, show, however that both measures are highly related. The mean number of PCNs in top- 5 positions is 0.51 for subsidiaries with a $\mathrm{HCN}$ as managing director and 2.53 for subsidiaries with a PCN as managing director (t-value: 15.93, sig. 0.000). If we treat the MD-nationality variable as a numerical variable, with either zero or one PCN in a particular subsidiary the correlation between the two measures is 0.7147 (sig. 0.000). Therefore, we feel that our data can be used as a proxy for the proportion of HCNs as used in Downes article.

${ }^{4}$ The difference between the number of questionnaires sent out and the number of cases in this research note is due to the fact that, for various reasons, some MNCs were not included for the mail survey.

${ }^{5}$ The Kompass and Dun \& Bradstreet address books were used for each country for which they were available. In addition to this Graham and Trotman's Major companies of Europe and Far East and Australasia and many country-specific address books e.g. Handbuch der Grossunternehmen and Handbuch der Mittelständische Unternehmen for Germany were used. Either the 1994/1995 or the 1995/1996 editions of these address books were used.

${ }^{6}$ As the division in two clusters for both political risk and cultural distance might be too crude, we also tried three and four clusters solutions (five cluster solutions were either not statistically different from each other or resulted in clusters containing only one country). Only the cluster with the lowest degree of political risk and the cluster with the highest degree of cultural similarity were used in the models. Cultural distance lost it significance, but remained negatively related to the chance of encountering a HCN. PD and IDV retained both their signs and their significance. MAS was positively related to the chance of a $\mathrm{HCN}$ in these two models, but did not achieve significance (sig. 0.41 and 0.64 respectively).

${ }^{7}$ I am grateful an anonymous reviewer for suggesting this point.

${ }^{8}$ Size is negatively correlated with the incidence of a $\mathrm{HCN}$ as managing director, while age shows a positive correlation.

${ }^{9}$ A random model's classification rate is equal to $\mathrm{a}^{2}+(1-\mathrm{a})^{2}$, where a is the proportion of HCNs in the sample (Morrison, 1974) 